Dicle Tıp Dergisi / Dicle Med J (2018) 45 (3) : 327-334

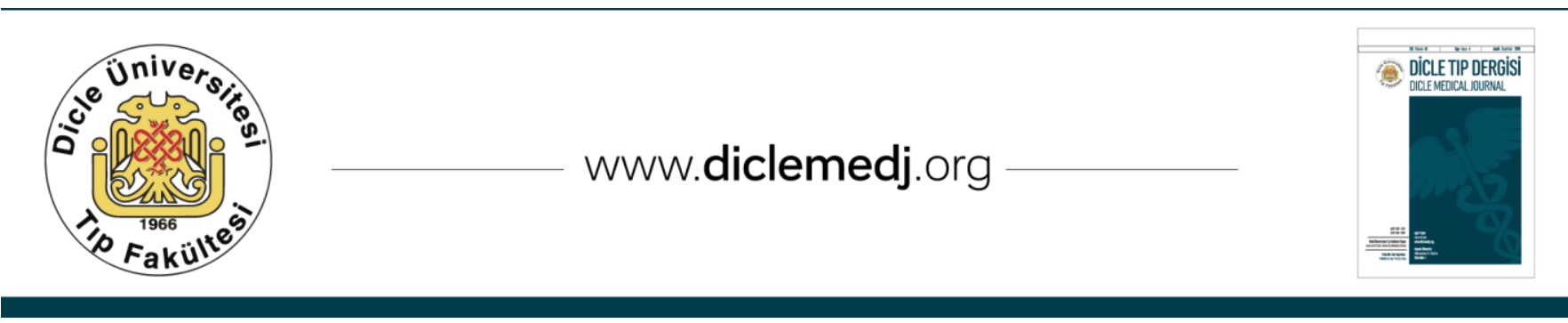

Özgün Araștırma / Original Article

\title{
Psöriazis vulgaris hastalarında nötrofil/lenfosit oranı, trombosit/lenfosit oranı, ortalama trombosit hacmi ve C-reaktif protein değerleri
}

\author{
İsa An"1, Derya Uçmak² \\ 1 Akçakale Devlet Hastanesi, Deri ve Zührevi Hastalıkları Kliniği, Şanlıurfa, Türkiye ORCID: 0000-0003-3366-4551 \\ 2 Dicle Üniversitesi, Deri ve Zührevi Hastalıkları Anabilim Dalı, Diyarbakır, Türkiye ORCID: 0000-0003-0675-5204
}

Geliș: 30.05.2018, Revizyon: 23.07.2018, Kabul Tarihi: 03.08.2018

Öz

Amaç: Son yıllarda nötrofil/lenfosit oranı (NLO), trombosit/lenfosit oranı (TLO),ortalama trombosit hacmi(OTH) ve C reaktif protein(CRP)'nin sistemik inflamasyonun önemli göstergeleri olduğu gösterilmiştir. Yapılan çalışmalarda psöriazis vulgaris hastalarında NLO, TLO, OTH ve CRP 'nin kontrol gurubuna göre daha yüksek olduğu gösterilmiştir. Çalışmamızda psöriazisli hastaların NLO, TLO, OTH ve CRP düzeyleri ölçüldü ve bu parametrelerin tırnak tutulumu, artrit varlığı, hastalık süresi ve PAŞİ skoru ile iliş̧kili olup olmadığı araştırıldı.

Yöntemler: Herhangi bir sistemik hastalığı, infeksiyöz hastalığı ve otoimmun hastalı̆̆ı olmayan 133 psöriazis vulgaris hastası ve 107 sağlıklı kontrol çalışmaya dahil edildi. Hastalar PAȘi skoruna göre hafif (PAŞi்<10) ve orta-şiddetli (PAȘI $\geq 10$ ) olarak 2 gruba ayrıldı.

Bulgular: Hasta grubundaki NLO, OTH ve CRP kontrol grubuna göre anlamlı olarak yüksek idi. (sırasıyla p=0.001, $\mathrm{p}=0.003, \mathrm{p}<0.001$ ). Hasta grubundaki TLO değeri, kontrol grubuna kıyasla düşük olmakla beraber aralarındaki fark istatistiksel olarak anlamlı değildi. (p:0,074) Psöriazisli hastalar arasında, OTH ve CRP değerleri orta-şiddetli grupta, hafif gruba göre yüksekti ve aradaki fark istatistiksel olarak anlamlıydı. (sırasıyla p:0,017, p<0.001). OTH ve CRP değerleri ile artrit varlığı, tırnak tutulumu ve hastalık süresi arasında istatistiksel olarak anlamlı bir ilişki saptanmadı. ( $>$ >0.05) NLO ve TLO değerleri ile PAŞi skoru, artrit varlığı, tırnak tutulumu ve hastalık süresi arasında istatistiksel olarak anlamlı bir ilişki saptanmadı. ( $\mathrm{p}>0.05)$

Sonuç: NLO ve CRP' nin psöriazis hastalarında inflamasyonu göstermede uygun bir parametre olduğu söylenebilir bununla birlikte NLO' nun hastalık şiddetiyle korele olmaması klinik kullanımını kısıtlayabilir. OTH' nın psöriazis hastalarında kontrollere göre daha yüksek olması ve PAȘi skoru ile ilișkili olması inflamasyon belirteci olarak kullanılmasının TLO ve NLO' ya kıyasla daha yararlı bir belirteç olduğunu göstermektedir.

Anahtar Kelimeler: Psöriazis vulgaris, nötrofil/lenfosit oranı, trombosit/lenfosit oranı, ortalama trombosit hacmi, CRP.

DOI: $10.5798 /$ dicletip. 457261

Yazıșma Adresi / Correspondence: İsa An, Akçakale Devlet Hastanesi, Deri ve Zührevi Hastalıkları Kliniği, Akçakale, Şanlıurfa, Türkiye e-mail: is_an89@hotmail.com 


\title{
Evaluation of neutrophil-to-lymphocyte ratio, platelet-to-lymphocyte ratio, mean platelet volume, and C-reactive protein in patients with psoriasis vulgaris
}

\begin{abstract}
Objective: Recent reports indicate that neutrophil-to-lymphocyte ratio (NLR), platelet-to-lymphocyte ratio (PLR), mean platelet volume (MPV), and C-reactive protein (CRP) are key markers of systemic inflammation. These markers have also been shown to be significantly increased in patients with psoriasis vulgaris compared to control subjects. In this study, we aimed to evaluate the relationship between serum levels of NLR, PLR, MPV, and CRP and nail involvement, presence of arthritis, duration of disease, and Psoriasis Area and Severity Index (PASI) scores in patients with psoriasis vulgaris.

Methods: The study included 133 patients with psoriasis vulgaris that had no systemic, infectious, or autoimmune diseases and a control group of 107 healthy volunteers. The patients were divided into two groups based on their PASI scores: (I) mild (PASI $<10)$ and (II) moderate-severe (PASI $\geq 10)$.

Results: NLR, MPV, and CRP values were significantly higher in the patient group compared to the control group $(p=0.001,0.003,<0.001$, respectively). PLR values were lower in the patient group compared to the control group although no significant difference was found $(\mathrm{p}=0.074)$. In the patient group, the MPV and CRP values were significantly higher in the patients with moderate-severe psoriasis vulgaris compared to the patients with psoriasis vulgaris ( $p=0.017$ and $<0.001$, respectively). No significant relationship was found between the MPV and CRP values and presence of arthritis, nail involvement, and duration of disease $(p>0.05)$. Similarly, no significant relationship was found between the NLR and PLR values and PASI score, presence of arthritis, nail involvement, and duration of disease $(\mathrm{p}>0.05)$.

Conclusion: NLR and CRP can be useful markers of inflammation in patients with psoriasis vulgaris; however, the absence of a correlation between NLR and the severity of disease may lead to a limitation in the clinical use of NLR. MPV can be a better marker of inflammation compared to PLR and NLR since it was significantly higher in the patients with psoriasis vulgaris compared to the healthy subjects and also correlated with the PASI score.
\end{abstract}

Keywords: Psoriasis vulgaris, neutrophil-to-lymphocyte ratio, platelet-to-lymphocyte ratio, mean platelet volume, CRP.

\section{GíRiş}

Psöriazis, $\quad \mathrm{T}$ hücre aracıll, eritemli, papüloskuamöz lezyonlarla karakterize, kronik, inflamatuar, sistemik bir hastalıktır. Hastalığın patogenezi tam olarak bilinmemektedir ${ }^{1}$. Hastalığın inflamatuar doğası TNF (tümör nekrotizan faktör)- $\alpha$, IFN (interferon) $\gamma$ ve çeşitli proinflamatuar sitokinlerin aşırı ekspresyonundan kaynaklanır².

Son yllarda nötrofil/lenfosit oranı (NLO), trombosit/lenfosit oranı (TLO), ortalama trombosit hacmi(OTH) ve C reaktif protein(CRP)' nin sistemik inflamasyonun önemli göstergeleri olduğu gösterilmiştir ${ }^{1-4}$. NLO ve TLO' nun psöriazis patogenezinde görev alan interlökin(IL)-6 ve TNF-alfa ile ilgili olduğu gösterilmiştir ${ }^{1,5}$.
Yapılan çalışmalarda psöriazis hastalarında NLO, TLO, OTH ve CRP' nin kontrol gurubuna göre daha yüksek olduğu gösterilmiştir ${ }^{1,4}$. Bu çalışmada psöriazisli hastaların NLO, TLO, OTH ve CRP düzeyleri ölçüldü ve bu parametrelerin tırnak tutulumu, artrit varlığı, hastalık süresi ve PAŞİ skoru ile ilişskili olup olmadığı araştırıldı.

\section{YÖNTEMLER}

Çalışmaya Ocak 2013 ve Eylül 2017 yılları arasında Üniversitemiz Dermatoloji polikliniğinde takip edilen, 18-77 yaş arası, 133 psöriazis vulgaris tanılı hasta ve herhangi bir nedenle polikliniğe başvurmuş, sistemik inflamatuar bir hastalığı olmayan ve takiplerinde hemogram testi istenmiş olan 107 birey kontrol grubu olarak dahil edildi. 
Hastalar ve kontrol grubunun cinsiyet, yaş, lenfosit sayısı, lökosit sayısı, nötrofil sayısı, trombosit sayısı, CRP, NLO, OTH ve TLO değerleri kaydedildi. Hastaların kayıtlarından hastalık süresi, tırnak tutulumu, artrit varlığı ve PAŞİ skorları geriye dönük olarak incelendi. Psöriazisli hastalar PAŞİ skoruna göre hafif (PAŞİ<10) ve orta-şiddetli (PAŞİ $\geq 10)$ olmak üzere 2 gruba ayrıldı.

Çalışmaya herhangi bir sistemik hastalığı, inflamatuar ve infeksiyöz hastalığı ve herhangi bir organda malignite öyküsü olan hastalar dahil edilmedi.

CRP değeri Beckman Coulter nefelometrik yöntem ile hesaplandı (IMMAGE 800, USA). Tam kan sayımı Cell-Dyn 3700 (optik scatter lazer yöntemi, Abbott Diagnostics, Chicago, USA) aracılığıyla hesaplandı. TLO değeri trombosit sayısının lenfosit sayısına bölünmesi ile hesaplandı. NLO değeri ise nötrofil sayısının lenfosit sayısına bölünmesi ile hesaplandı.

İstatistiksek analizler SPSS 21.0 for Windows (SPSS Inc., Chicago, IL, USA) programı kullanılarak yapıldı. İstatistiksel olarak p $<0.05$ anlamlı olarak kabul edildi. Receiver-operating characteristic (ROC) curve analiz psöriazis vulgarisi öngörmede NLO, TLO ve OTH eşik değerini saptamak amacıyla kullanıldı.

\section{BULGULAR}

Çalışmamızda cinsiyet oranı ve yaş bakımından psöriazisli hastalarla (74 erkek, 59 kadın; ort \pm ss yaş $36.6 \pm 14.4$ ), kontroller (52 erkek, 55 kadın; ort \pm ss yaş $35.7 \pm 14.5$ ) arasında istatistiksel olarak anlamlı bir fark saptanmadı. ( $\mathrm{p}>0.05)$

Psöriazisli hastaların ortalama hastalık süresi $11.0 \pm 7.9$ yll ve ortalama PAȘI skoru $12,2 \pm 7.3$ idi.

Psöriazisli hastaların $50(\% 37,5)^{\prime}$ inde tırnak tutulumu, 20(\% 15)' inde ise artrit mevcuttu.

Psöriazisli hastaların nötrofil sayısı $6.26 \pm 1.59 \times 103$, kontrollerin nötrofil sayısı $4.33 \pm 1.12 \times 103$ olarak saptand. Psöriazisli hastaların ve kontrol grubunun nötrofil sayısı arasındaki fark anlamlıydı $(\mathrm{p}<0.001)$.
Psöriazisli hastalar, PAȘI skoruna göre hafif (PAŞİ<10) ve orta-şiddetli (PAȘI $\geq 10)$ olarak 2 gruba ayrılarak incelendiğinde nötrofil sayısı orta-şiddetli grupta $7.06 \pm 1.22 \times 103$, hafif grupta $5.07 \pm 1.31 \times 103$ olarak saptandl. Hafif ve orta-şiddetli grup arasındaki fark anlamlıydı.( $\mathrm{p}<0.001$ )

Psöriazisli hastaların lenfosit sayısı $2.62 \pm 0.55$ $\mathrm{x} 103$, kontrollerin lenfosit sayıs $2.42 \pm 0.79$ x103 olarak saptandı. İki grup arasındaki fark anlamlı değildi (p:0,025).

Psöriazisli hastaların NLO değeri 2.56 \pm 1.75 , kontrollerin NLO değeri 1.95 \pm 0.81 olarak saptandı. İki grup arasındaki fark anlamlıydı (p:0.001).

ROC analizine göre NLO değerinin 2.00 olmasının psöriazisi öngörmedeki sensitivitesi $\% 69$ spesifitesi \%70 idi. (AUC:0,716, p<0.001) (Resim 1).

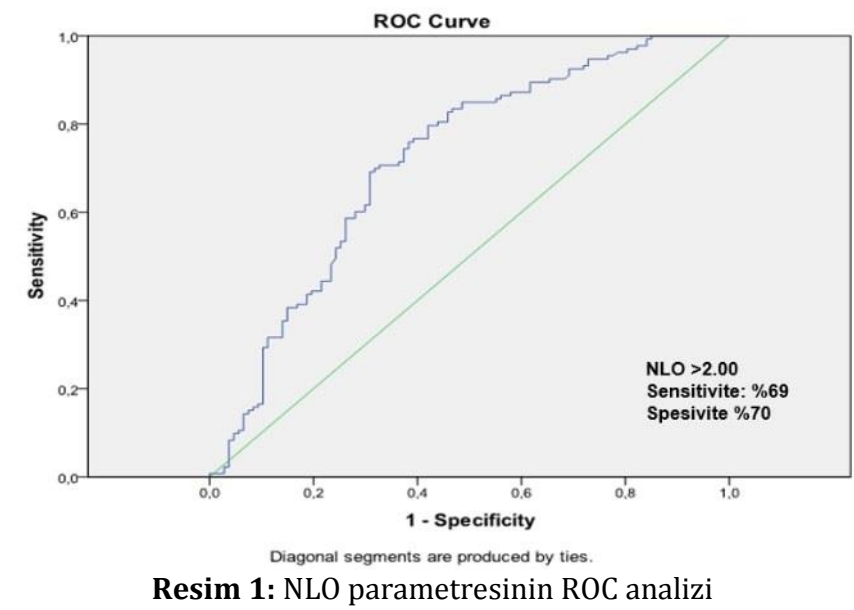

NLO orta-şiddetli grupta $2.72 \pm 0.62$, hafif grupta $2.32 \pm 2.64$ olarak saptandı. İki grup arasındaki fark anlamlı değildi (p:0,193).

Psöriazisli hastaların TLO değeri 110.86 \pm 65.66 kontrollerin TLO değeri 125.52 \pm 59.03 olarak saptandı. İki grup arasındaki fark anlamlı değildi (p:0,074).

TLO orta-şiddetli grupta 106.8 \pm 24.8 , hafif grupta 116.6 \pm 98.8 olarak saptandı. İki grup arasındaki fark anlamlı değildi (p:0,400).

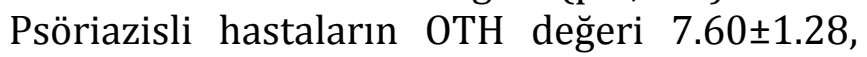
kontrollerin OTH değeri 7.15 \pm 0.94 olarak 
saptandı. İki grup arasındaki fark anlamlıydı (p:0.003).

ROC analizine göre OTH değerinin 0,722 olmasının psöriazisi öngörmedeki sensitivitesi \%55 spesifitesi \%62 idi. (AUC: 0,590, p:0.017) (Resim 2).

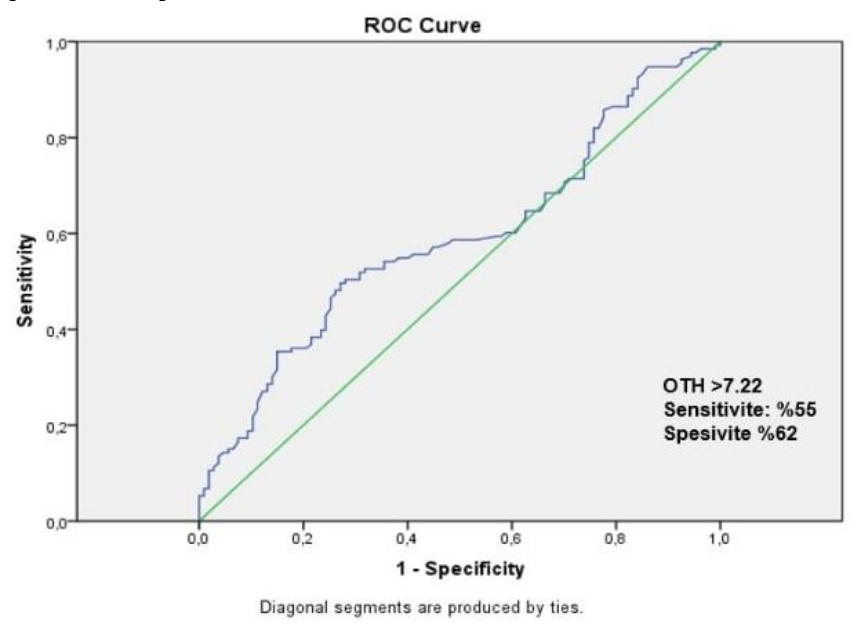

Resim 2: OTH parametresinin ROC analizi

OTH orta-şiddetli grupta: $7.82 \pm 1.24$, hafif grupta $7.29 \pm 1.28$ olarak saptandl. İki grup arasındaki fark anlamlıydı (p:0,017).

Psöriazisli hastaların CRP değeri 1.18 \pm 1.04 , kontrollerin CRP değeri $0.57 \pm 0.76$ olarak saptandı. İki grup arasındaki fark anlamlıydı $(\mathrm{p}<0.001)$.

ROC analizine göre CRP değerinin 0,505 olmasının psöriazisi öngörmedeki sensitivitesi $\% 61$ spesifitesi \%80 idi. (AUC:0,686, p<0.001) (Resim 3).

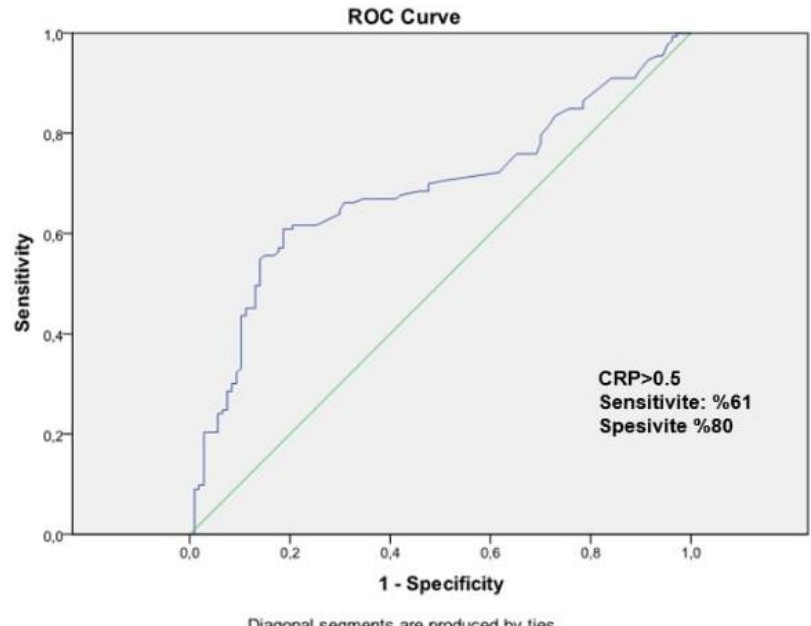

Resim 3: CRP parametresinin ROC analizi
CRP orta-şiddetli grupta $1.79 \pm 0.95$, hafif grupta $0.29 \pm 0.12$ olarak saptandı. İki grup arasındaki fark anlamlıydı $(\mathrm{p}<0.001)$.

NLO, TLO, OTH ve CRP ile hastalık süresi, artrit varlığı ve tırnak tutulumu arasında anlamlı bir ilişki bulunamadı ( $\mathrm{p}>0.05)$.

Psöriazisli hastalar ve sağlıklı kontrollerin demografik ve klinik özellikleri Tablo 1 de belirtilmiştir (Tablo1).

Tablo 1: Psöriazisli hastalar ve sağlıklı kontrollerin demografik ve klinik özellikleri

\begin{tabular}{|c|c|c|c|}
\hline & \begin{tabular}{|l|} 
Psöriazis vulgaris \\
(n:133)
\end{tabular} & $\begin{array}{l}\text { Sağlıklı kontrol } \\
\text { (n:107) }\end{array}$ & $P$ değeri \\
\hline Yaş(ort $\pm S S$, yll) & $36.6 \pm 14.4$ & $35.7 \pm 14.5$ & 0,642 \\
\hline Cinsiyet(erkek/kadın) & $74 / 59$ & $52 / 55$ & $>0.05$ \\
\hline \begin{tabular}{|l|} 
Hastalık \\
süresi(ort $\pm S S, y ı l)$ \\
\end{tabular} & $11.0 \pm 7.9$ & & \\
\hline PAȘI skoru(ort $\pm S S$ ) & $12,2 \pm 7.3$ & & \\
\hline Nötrofil sayısı(ort $\pm S S$ ) & $6.26 \pm 1.59 \times 10^{3}$ & $4.33 \pm 1.12 \times 10^{3}$ & $<0.001$ \\
\hline Lenfosit sayısı(ort \pm SS) & $2.62 \pm 0.55 \times 10^{3}$ & $2.42 \pm 0.79 \times 10^{3}$ & 0,025 \\
\hline \begin{tabular}{|l} 
Trombosit \\
sayısı(ort $\pm S S$ )
\end{tabular} & $270 \pm 45.5 \times 10^{3}$ & $287 \pm 180 \times 10^{3}$ & 0,352 \\
\hline $\mathrm{NLO}($ ort $\pm \mathrm{SS})$ & $2.56 \pm 1.75$ & $1.95 \pm 0.81$ & 0,001 \\
\hline TLO(ort $\pm S S$ ) & $110.86 \pm 65.66$ & $125.52 \pm 59.03$ & 0,074 \\
\hline OTH(ort \pm SS) & $7.60 \pm 1.28$ & $7.15 \pm 0.94$ & 0,003 \\
\hline $\mathrm{CRP}($ ort $\pm \mathrm{SS}, \mathrm{mg} / \mathrm{L})$ & $1.18 \pm 1.04$ & $0.57 \pm 0.76$ & $<0.001$ \\
\hline
\end{tabular}

Psöriazisli hastalardaki PAȘí skoru ile inflamatuar parametreler arasındaki ilişki Tablo 2 de belirtilmiştir (Tablo2).

\section{TARTIŞMA}

Psöriazis toplumda \%2-3 oranında görülen, genellikle diz, dirsek, sakral bölge ve ekstremitelerin ekstansör yüzlerini tutan kronik inflamatuar bir hastalıktır. Hastalığın patogenezi tam olarak bilinmemekle birlikte genetik ve çevresel etkenlerin birlikte rol aldığı düşünülmektedir. Lezyonların histolojik incelemesinde $\mathrm{T}$ lenfosit ve nötrofilden zengin hücre infiltrasyonu görülür6.

Sistemik inflamasyonda nötrofiller savunmanın ilk basamağını başlatırlar ve aktif nonspesifik inflamasyonu gösterirler. Lenfositler ise 
inflamasyonun düzenleyici ve koruyucu bileşenini oluştururlar ${ }^{7}$. Yapılan çalışmalarda psöriazisin hem plak lezyonlarında hem de periferik kanda nötrofil aktivasyon ürünlerinin artmış olduğu gösterilmiştir ve bu ürünlerin hastalığın patogenezine katkı sundukları düşünülmektedir6,8. Psöriaziste potent bir nötrofil kemotaktik faktör olan CXCL8'in plazma seviyelerinin artmasından dolayı lökositler ve nötrofiller artmaktadır ${ }^{9}$.

Tablo2: Psöriazisli hastalardaki PAȘİ skoru ile inflamatuar parametreler arasındaki ilișki

\begin{tabular}{|l|l|l|l|}
\hline & PAȘi $<10$ (n:54) & PAȘi $\geq 10$ (n:79) & P değeri \\
\hline $\begin{array}{l}\text { Nötrofil sayıSı } \\
\text { (ort } \pm S S)\end{array}$ & $5.07 \pm 1.31 \times 10^{3}$ & $7.06 \pm 1.22 \times 10^{3}$ & $<0.001$ \\
\hline $\begin{array}{l}\text { Lenfosit sayısı } \\
\text { (ort } \pm S S)\end{array}$ & $2.56 \pm 0.62 \times 10^{3}$ & $2.66 \pm 0.50 \times 10^{3}$ & 0.321 \\
\hline $\begin{array}{l}\text { Trombosit sayısı } \\
\text { (ort } \pm S S)\end{array}$ & $261 \pm 43 \times 10^{3}$ & $276 \pm 46 \times 10^{3}$ & 0.076 \\
\hline NLO(ort $\pm S S)$ & $2.32 \pm 2.6$ & $2.72 \pm 0.6$ & 0.193 \\
\hline TLO(ort $\pm S S)$ & $116.68 \pm 98.85$ & $106.88 \pm 24.84$ & 0.400 \\
\hline OTH(ort $\pm S S)$ & $7.29 \pm 1.28$ & $7.82 \pm 1.24$ & 0.017 \\
\hline CRP(ort $\pm S S, m g / L)$ & $0.29 \pm 0.12$ & $1.79 \pm 0.95$ & $<0.001$ \\
\hline
\end{tabular}

Ünal ve ark. çalışmasında psöriazis hastalarında nötrofil sayısı kontrol grubundan daha yüksek bulunmuştur. Lenfosit sayısı ise kontrol grubuna göre daha düşük bulunmuştur ${ }^{1}$. Rocha-Pereira ve ark. çalışmasında psöriazis hastalarında nötrofil sayısınının arttığı belirtilmiştir. Fakat bu çalışmada farklı olarak aktif ve inaktif psöriazis hastaları da kıyaslanmış ve aktif psöriazisli hastalarda nötrofil sayısının inaktif hastalara göre anlamlı olarak yüksek olduğu gösterilmiştir7.

Çalışmamızdaki psöriazisli hastaların nötrofil sayısı literatürdeki çalışmalarla benzer şekilde kontrollerin nötrofil sayısına göre yüksekti ve orta-şiddetli grupta nötrofil sayısı hafif gruptaki hastalara göre daha yüksekti.

NLO, toplam nötrofil sayısının lenfosit sayısına bölünmesiyle elde edilir. Ucuz olması ve kolayca hesaplanabilmesi önemli avantajlarıdır. Toplumda yaygın olarak görülen ve inflamasyon ile giden metabolik sendrom, uyku apne sendromu, hiperkolestrolemi, derin boyun enfeksiyonları, renal hastalıklar ve maligniteler gibi birçok hastalıkta NLO' nun arttığı gösterilmiştir ${ }^{10-13}$. Psöriaziste arttığ bilinen TNF $\alpha$ ve çeşitli sitokinlerin düzeylerinin artmasının NLO' da yükselmeye neden olduğu gösterilmiştir ${ }^{1}$.

Ünal ve ark. çalışmasında psöriazis hastalarındaki NLO değerleri kontrol grubundaki NLO değerlerine göre daha yüksek saptanmıştır ve ayrıca NLO ile CRP arasında pozitif korelasyon saptanmıştır ${ }^{1}$.

Kim ve ark. psöriazisli hastalarda NLO' nun kontrollere oranla arttığını ve ayrıca NLO ile PAȘİ skoru arasında pozitif bir korelasyon bulunduğunu göstermişlerdir ${ }^{14}$. İki ayrı çalışmada da benzer şekilde NLO değerleri ve PAŞİ skoru arasında pozitif korelasyon saptanmıştır 8,15 .

Ataseven ve ark. NLO değeri ile PAŞİ skorları arasında bir ilişki bulamamıştır. Bu durumun PAŞİ skoru düşük olan hastaların çalışmaya alınmasından kaynaklandığını belirtmişlerdir ${ }^{16}$.

Çerman ve ark. çalışmasında psöriazis hastalarında kontrollere göre NLO düzeyleri anlamlı olarak yüksek bulunmuştur. Ancak hastalar hastalık şiddetine göre ayrıldığında hafif grupla orta-şiddetli grup arasında anlamlı bir fark görülmemiştir ${ }^{17}$.

Bizim çalışmamızda NLO, literatürdeki çalışmalarla benzer şekilde psöriazis hastalarında kontrollere göre belirgin şekilde yüksekti. NLO ile CRP düzeyi, hastalık süresi, artrit varlığl, PAŞİ skoru ve tırnak tutulumu arasında istatistiksel olarak herhangi bir ilişki saptanmadl.

Trombositler zengin bir inflamatuar sitokin kaynağıdır ve bağışıklık hücreleri üzerinde düzenleyici etkilere sahip olup enflamasyonda aktif rol oynamaktadirlar. Trombosit aktivasyonunun psöriazis patogenezinde rol oynadığı belirtilmiştir ${ }^{11,12}$. 
Son yıllarda trombosit sayısının lenfosit sayısına bölünmesi ile hesaplanan TLO değerinin inflamasyon belirteci olarak kullanılabileceği belirtilmiștir¹.

Asahina ve ark. çalışmasında TLO' nun psöriyazisli hastalarda PAȘİ skoru ile pozitif bir ilişkisi olduğu ve sistemik enflamasyonu yansıttığı gösterilmiştir. TLO' nun ayrıca hastalık seyrini izlemek için, özellikle tedaviden sonra sistemik enflamasyonun inhibisyonunu değerlendirmek için de kullanılabileceği belirtilmiştir4.

Yurtdaş ve ark. ${ }^{18}$ ve Kim ve ark. ${ }^{13}$ psöriazisli hastalarda TLO' nun kontrollerle karşılaştırıldığında önemli bir farklılık göstermediğini belirtmişlerdir. Fakat Kim ve ark. çalışmasında TLO ve PAȘi skorları arasında pozitif korelasyon gösterilmiştir ${ }^{13}$.

Bizim çalışmamızda TLO, literatürdeki verilerden farklı olarak psöriazis hastalarında kontrollere göre düşüktü fakat bu düşüklük istatistiksel olarak anlamlı değildi. TLO ile artrit varlığı, tırnak tutulumu, hastalık süresi ve hastalık şiddeti arasında istatistiksel olarak anlamlı bir ilişki saptanmadı.

OTH, trombosit büyüklüğünün en yaygın olarak kullanılan ölçüsüdür ve büyük trombositler metabolik ve enzimatik olarak daha aktif oldukları için, trombosit reaktifliğinin in vivo bir göstergesi olarak kabul edilir. OTH değerinin artması akut MI, hiperlipidemi ve DM için bağımsız bir risk faktörü olarak kabul edilmektedir ${ }^{19-21 .}$

Ünal ve ark. ve Karabudak ve ark. çalışmalarında psöriazisli hastalarda kontrollere göre OTH değeri daha yüksek bulunmuştur ${ }^{1,3}$. Çerman ve ark. ve Saleh ve ark. çalışmalarında ise psöriazisli hastalar ve kontroller arasında OTH düzeyi yönünden anlamlı bir fark saptanmamıștır ${ }^{17,22}$.

Asahina ve ark. çalışmasında psöriazisli hastalarda OTH ile artrit varlığı arasında negatif korelasyon olduğu belirtilmiştir4.
Çerman ve ark. çalışmasında ise psöriazisli hastalarda PAŞİ skoru ile OTH arasında herhangi bir korelasyon saptanmamıştır ${ }^{17}$.

Bizim çalışmamızda OTH, psöriazis hastalarında kontrollere göre belirgin şekilde yüksekti ve orta-şiddetli gruptaki OTH değeri hafif gruptaki hastalara göre daha yüksekti. OTH ile artrit varlığı, hastalık süresi ve tırnak tutulumu arasında anlamlı bir ilişki saptanmadı. OTH' nın psöriazis hastalarında kontrollere göre daha yüksek olması ve PAŞi skoru ile pozitif ilişkisinin olması psöriazis hastalarında TLO ve NLO' dan daha iyi bir inflamasyon belirteci olduğunu göstermektedir.

C-reaktif protein (CRP), ağırlıklı olarak hepatositler tarafindan IL-6 ve TNF- $\alpha$ gibi sitokinlerin etkisi altında üretilen bir akut faz proteindir. Psöriazisli hastalarda serum CRP düzeylerinin belirgin şekilde yüksek olduğu ve CRP düzeyleri ile hastalık şiddeti arasında pozitif korelasyon olduğu gösterilmiştir ${ }^{23}$.

Beygive ark. çalışmasında psöriazisli hastalarda CRP düzeyinin tedavi sonrası düştüğü ve takipte kullanılabileceği belirtilmiştir ${ }^{24}$.

Bizim çalışmamızda CRP, psöriazis hastalarında kontrollere göre belirgin şekilde yüksekti ve orta-şiddetli gruptaki CRP değeri, hafif gruptaki hastalara göre daha yüksekti. CRP ile artrit varlığı, tırnak tutulumu ve hastalık süresi arasında istatistiksel olarak anlamlı bir ilişki saptanmadi.

\section{SONUÇ}

Sonuç olarak çalışmamızda TLO, psöriazis hastalarında kontrollere göre düşük saptandı ayrıca TLO ile artrit varlığı, tırnak tutulumu, hastalık süresi ve PAŞi skoru arasında istatistiksel olarak anlamlı bir ilişki saptanmadı. Bu verilere dayanılarak TLO' nun psöriazis hastalarında inflamasyonu göstermede uygun bir parametre olmadığı söylenilebilir. NLO psöriazis hastalarında kontrollere göre yüksek olmasına rağmen PAŞİ skoru, eklem tutulumu, tırnak tutulumu ve 
hastalık süresi gibi hastalık karakteristikleriyle anlamlı bir ilişkisi görülmedi. NLO' nun psöriazis hastalarında inflamasyonu göstermede uygun bir parametre olduğu fakat hastalık şiddetini göstermede uygun bir parametre olmadığı söylenilebilir. CRP 'nin psöriazis hastalarında kontrollere göre daha yüksek olması ve PAŞI skoru ile pozitif ilișkisinin olması psöriazis hastalarında inflamasyon belirteci olarak kullanılabileceğini göstermektedir. OTH' nın psöriazis hastalarında kontrollere göre daha yüksek olması ve PAȘI skoru ile pozitif ilișkisinin olması psöriazis hastalarında inflamasyon belirteci olarak TLO ve NLO' dan daha iyi bir belirteç olduğunu göstermektedir.

$\mathrm{Bu}$ çalışma 3. Ulusal Psöriazis Sempozyumu'nda 29 Mart- 1 Nisan 2018' te Antalya'da sözel bildiri olarak sunulmuştur.

Çıkar Çatışması Beyanı: Yazarlar çıkar çatışması olmadığını bildirmişlerdir.

Finansal Destek: Bu çalışma herhangi bir fon tarafından desteklenmemiştir.

Declaration of Conflicting Interest: The authors declare that they have no conflict of interest.

Financial Disclosure: No financial support was received.

\section{KAYNAKLAR}

1.Unal M, Kucuk A, Unal GU, et al. Mean platelet volume, neutrophil to lyphocyte ratio and platelet to lymphocyte ratio in psoriasis. Turkderm. 2015; 49: 112-6.

2. Gaspari AA. Innate and adaptive immunity and the pathophysiology of psoriasis. J Am Acad Dermatol.2006; 54: 67-80.

3. Karabudak O, Ulusoy RE, Erikci AA, Solmazgul E, Dogan B,Harmanyeri Y. Inflammation and hypercoagulable state in adult psoriatic men. Acta Derm Venereol. 2008; 88: 337-40.
4. Asahina A, Kubo N, Umezawa Y, Honda H, Yanaba K, Nakagawa $\mathrm{H}$. Neutrophil-lymphocyte ratio, plateletlymphocyte ratio and mean platelet volume in Japanese patients with psoriasis and psoriatic arthritis: Response to therapy with biologics. J Dermatol. 2017; 44: 1112-21.

5. Turkmen K, Erdur FM, Ozcicek F, et al. Platelet-tolymphocyte ratio better predicts inflammation than neutrophil-to-lymphocyte ratio in end-stage renal disease patients. Hemodial Int. 2013; 17: 391-6.

6. Krueger G, Ellis CN. Psoriasis - recent advances in understanding its pathogenesis and treatment. J Am Acad Dermatol. 2005; 53: 94-100.

7. Rocha-Pereira P, Santos-Silva A, Rebelo I, Figueiredo A, Quintanilha A, Teixeira $F$. The inflammatory response in mild and in severe psoriasis. Br J Dermatol. 2004; 150: 917-28.

8. Sen BB, Rifaioglu EN, Ekiz O, Inan MU, Sen T, Sen N. Neutrophil to lymphocyte ratio as a measure of systemic inflammation in psoriasis. Cutan Ocul Toxicol. 2014; 33: 223-7.

9. Orem A, Deger O, Cimsit G, Bahadır S. Plasma polymorphonuclear leukocyte elastase levels and its relation to disease activity in psoriasis. Clin Chim Acta.1997; 264: 49-56.

10. Balta S, Cakar M, Demirkol S, Arslan Z, Akhan M. Higher neutrophil to lymphocyte ratio in patients with metabolic syndrome. Clin Appl Thromb Hemost. 2013; 19: 579.

11. Cemil BC, Atas H. The Effect of Biological Treatment onto Systemic Inflammatory Markers and Plateletcrit in Psoriasis Patients. Dicle Med J. 2016; 43: 477-83.

12- Gunabatar H, Ekin S, Sunnetcioglu $H$, et al. The relationship between neutrophil-to-lymphocyte ratio and platelet-to-lymphocyte ratio in patients with obstructive sleep apnea syndrome. Dicle Med J. 2015; 42: 289-93.

13. Sengül E,Ozbay M, Topcu I. Relationship between Neutrophil-to-Lymphocyte Ratio and Prognosis in Patients with Deep Neck Space Infection. Dicle Med J. 2016; 43: 126-9.

14. Kim DS, Shin D, Lee MS, et al. Assessments of neutrophil to lymphocyte ratio and platelet to lymphocyte ratio in Korean patients with psoriasis vulgaris and psoriatic arthritis. J Dermatol. 2016; 43: 305-10. 
15. Yurtdaş M, Yaylali YT, Kaya Y, et al. Neutrophilto Lymphocyte Ratio May Predict Subclinical Atherosclerosis in Patients with Psoriasis. Echocardiography. 2014; 31: 1095-104.

16. Ataseven A, Bilgin AU, Kurtipek GS. The importance of neutrophil lymphocyte ratio in patients with psoriasis. Clin Med Res. 2014; 3: 40-3.

17. Cerman AA, Karabay EA, Altunay IK. Evaluation of neutrophil-lymphocyte ratio and mean platelet volume in patients with psoriasis. SETB. 2016; 50: 137-41

18. Yurtdas M, Yaylali YT, Kaya Y et al. Neutrophil-tolymphocyte ratio may predict subclinical atherosclerosis in patients with psoriasis. Echocardiography. 2014; 31: 1095-104.

19. Chu SG, Becker RC, Berger PB, et al. Mean platelet volume as a predictor of cardiovascular risk: a systematic review and meta-analysis. J Thromb Haemost. 2010; 8: 148-56.
20. Incebıyık A, Uyanıkoglu H. Is there a role mean platelet volume in the diagnosis of patients with adnexal torsion? Dicle Med J. 2017; 44: 333-7.

21- Sahpaz P,Ulutas KT. Assessment of mean platelet volume in type 2 diabetics receiving insulin or oral antidiabetic agents. Dicle Med J. 2015; 42: 399-403.

22. Saleh HMA, Attia EAS, Onsy AM, Saad AA, Abd Ellah MMM. Platelet activation: a link between psoriasis per se and subclinical atherosclerosis - a case - control study. Br J Dermatol. 2013; 169: 68-75.

23. Coimbra S, Oliveira H, Reis F, et al. C-reactive protein and leucocyte activation in psoriasis vulgaris according to severity and therapy. J Eur Acad Dermatol Venereol. 2010; 24: 789-96.

24. Beygi S, Lajevardi V, Abedini R. C-reactive protein in psoriasis: a review of the literatüre. JEADV. 2014; 28: 700-11. 